\title{
Acceptance of Tourist Offers and Territory: Cluster Analysis of Ibiza Residents (Spain)
}

\author{
José Ramón-Cardona ${ }^{1}(\mathbb{D})$, David Daniel Peña-Miranda ${ }^{2, *}(\mathbb{D})$ and María Dolores Sánchez-Fernández ${ }^{3}(\mathbb{D}$ \\ 1 Ibiza Island Council University College of Tourism, University of the Balearic Islands, 07800 Ibiza, Spain; \\ jose.ramon@uib.es \\ 2 Faculty of Business and Economic Sciences, Universidad del Magdalena, Carrera 32 No. 22-08, \\ Santa Marta 470004, Colombia \\ 3 Department of Business, University of A Coruña, 15071 A Coruña, Spain; maria.sanchezf@udc.es \\ * Correspondence: ddpena@unimagdalena.edu.co; Tel.: +57-3012516006
}

Citation: Ramón-Cardona, J.;

Peña-Miranda, D.D.;

Sánchez-Fernández, M.D. Acceptance of Tourist Offers and Territory:

Cluster Analysis of Ibiza

Residents (Spain). Land 2021, 10, 734.

https://doi.org/10.3390/land10070734

Academic Editor: Alastair

M. Morrison

Received: 18 June 2021

Accepted: 6 July 2021

Published: 13 July 2021

Publisher's Note: MDPI stays neutral with regard to jurisdictional claims in published maps and institutional affiliations.

Copyright: (c) 2021 by the authors. Licensee MDPI, Basel, Switzerland. This article is an open access article distributed under the terms and conditions of the Creative Commons Attribution (CC BY) license (https:// creativecommons.org/licenses/by/ $4.0 /)$.

\begin{abstract}
Heterogeneity studies have analyzed different clusters of residents according to their perception and attitude toward tourism in general or a specific type of tourism, but there are still no studies on the heterogeneity in the acceptance of tourist offers. The aim of this article was to segment residents according to their acceptance of different tourist offers focused on the territory. This is a new approach that seeks to determine the profiles of residents based on their preferences for the future development of a destination's offer in order to solve land-related problems. Cluster analysis carried out by the K-means algorithm made it possible to create five clusters: Disappointed, favorable with nuances, moderate, enthusiasts but anti-nightclub, and enthusiasts. The clusters were characterized by the rejection of the "all inclusive" offer and by the acceptance of most offers. The types of tourism that involve an enhancement of the landscape and heritage were shown to be the best valued. The differences between the clusters were marked by the degree of general acceptance and by the rejection of some offers considered "conflicting." The offers that imply a high consumption of land (golf courses) or annoyances from the immediate surroundings (nightclubs) generated discrepancies.
\end{abstract}

Keywords: residents; attitudes; Ibiza; offers; cluster analysis; territory

\section{Introduction}

Tourism activity has the peculiarity of taking place in a geographic space shared by the resident population, and residents' actions are also essential for the success of the tourist experience. This implies that it is necessary to have the acceptance of the local population, and to get residents to support and get involved in the tourism sector [1-5]. This means that destination marketing organizations (DMOs) must analyze and take into account the opinions, attitudes, and actions of the resident population, since the sustainable development of the sector is not possible otherwise [1,6-10]. These opinions, attitudes, and actions should be the starting point aimed at minimizing the negative effects of tourism, usually environmental and sociocultural, and maximizing the positive effects, usually economic $[1,11]$.

The academic literature on residents' attitudes most commonly focuses on analyzing the impact of perceptions and their relationship with residents' attitudes, expressed in the form of actions or opinions [12-18]. These studies do not normally take into account the heterogeneity of the population under study, mainly because it is not the objective of this type of analysis. Heterogeneity is easily verifiable, and research focused on segmenting residents according to their attitudes toward tourism have demonstrated this for more than 40 years, detecting groups that are clearly in favor of tourism living with groups that are clearly against tourism $[1,2,19]$. 
These analyses of the heterogeneity of residents' attitudes are very important for understanding how the same action of BMOs can have different effects on different people. Although the papers that analyze this issue date back to the 1970s, in recent years, research in this area has increased and, based on the various case studies that these papers represent, it has been possible to propose the first theoretical models [19].

The aim of this article was to deepen the analysis of the heterogeneity of residents' attitudes by carrying out a cluster analysis of Ibiza residents (Spain) according to their degree of acceptance of various types of tourism offer. This is a new approach that seeks to determine the profiles of residents based on their preferences regarding the future development of a destination's tourism sector. Almost all previous papers on residents ${ }^{\prime}$ segmentation substantiate the analysis of how tourism impacts perceptions, but in this case, the analysis took into consideration the degree of acceptance of offers. The research questions that lead to the realization of this cluster analysis are: Will groups appear with clear differences in their attitudes? Are these possible differences materialized in the degree of general acceptance of tourism or in preferences between the different types of tourism offer?

Regarding the case study, Ibiza is an island of $573 \mathrm{~km}^{2}$ and 150,000 inhabitants [20] and has a strong economic dependence on tourism. Traditionally, Ibiza has been characterized by a dispersed habitat that today is largely maintained. The result is that the population, houses, and roads are interspersed with forests and farmlands.

The island's greatest tourist development began in the 1950s and continued until the 1970s, although it has continued to grow at a variable rate since then [21]. Tourism development has been concentrated in the coastal areas, but over time, it has spread toward inland areas, usually in the form of dispersed and integrated urbanization within pine forests. Its tourist image is based on the beaches, the freedom linked to the hippie movement, and the glamour of the rich and famous in recent years. As the authors further state [21], the main offer is sun and beach tourism, completed by luxury establishments and nightlife offers. In recent years, luxury rental villas located in rural or forested inland areas have become popular, being one of the most impressive elements of Ibiza's luxury offer [21].

\section{Literature Review}

The main lines of research on residents' attitudes focus on the effect of causal variables on the estimated response $[8,13,22-24]$. In these cases, residents' attitudes are considered as a homogeneous parameter, because it is not their objective to analyze the heterogeneity of the sample but rather the causes and effects of these attitudes. There is a group of studies that propose an evolution of tourist destinations and, consequently, an evolution of residents' attitudes throughout a destination's history. The best-known models are those proposed by Doxey [25] and Butler [26], leaving a profound mark on multiple subsequent studies [27]. It should be noted that in these models, attitudes are considered different over time, but they do not propose the possibility of different groups at a given moment. Additionally, when sociodemographic variables of individuals are taken into account (age, job, sex, etc.), it is not uncommon to observe differences within a sample [28].

In addition to the variables that cause attitudes, the variability of residents' attitudes within a specific time and place should be analyzed to improve the results of the actions taken by the DMOs. The starting point of residents' attitudes is usually characterized by the predominance of favorable, positive, or enthusiastic groups with tourism development when it is necessary to develop the local economy [29-31]. For 40 years, the heterogeneity of residents' attitudes has been analyzed by performing segmentations using various techniques. However, at all times, it must be made clear that the techniques of segmentation only allow an approximation of the reality of a society, where there are no two people with exactly the same attitude, opinion, or behavior. One of the first segmentations of residents based on their attitude toward tourism was carried out on the island of Skye, Scotland [32], 
and later came other papers with diverse results, although with similarities, some of which are mentioned in Table 1.

Normally, segmentations are carried out by cluster analysis, but different algorithms are often used, which, together with the differences in the analyzed regions, provide results that are not totally comparable. Even so, there are similarities in the results obtained, especially in some profiles of residents that tend to be repeated [19]. These groups that recur with great frequency are:

- Between 10\% (mature destinations) and 50\% (incipient destinations) of the sample are clear enthusiastic advocates of tourism development in the region [19]. The most enthusiastic supporters are given different names: lovers [11,33-37], enthusiasts [38-40], supporters [1,41-45], development supporters [46-48], tourism supporters [49], favorers [50], optimists [51,52], absolute supporters [53], developers [49], high-supporters [54], enthusiastic supporters [55], etc. This resident profile magnifies the positive effects of tourism development, especially economic improvements, and minimizes the negative effects, usually social and environmental. They are usually people who have greatly improved, or hope to greatly improve, their personal economic situation thanks to tourism.

- Between 10\% (emerging destinations) and 30\% (mature destinations) are critical or contrary to tourism development in the region [19]. The tourism detractors are called: haters [33-36], somewhat irritated [39,40,55], opponents [44,45,56], cynics [44], critics [37,38,41], protectionists [46,47,49], opposers [1,50], pessimists [51], skeptics [48], low-supporters [54], etc. This group shows higher concern about the negative effects of tourism and would prefer a decrease in the tourism sector. Normally, they are people without a personal economic benefit derived directly from the tourism sector and who work in sectors that are very disconnected from tourism. For them, tourism only contributes negatively and is a nuisance or inconvenience.

Apart from these two main groups that always appear, there are other intermediate profiles that appear more or less recurrently. The equivalences between studies, in relation to these other groups, are quite difficult to determine due to the methodology and number of groups used in each case [34]. These intermediate groups usually show different degrees of acceptance of tourism, but with nuances and a more or less important recognition of the negative and positive impacts [19].

In mature tourist destinations (regions with strong development and dependence on the tourism sector), there is a group of residents who appear quite frequently. They are people with a high awareness of the effects of tourism development, both positive and negative. In addition, this group recognizes the importance of tourism for the region and the economic dependence that the local population has on the tourism sector [19]. This recognition of positive and negative elements has led to the group being called realists [34,35,57,58]. Clusters of cautious supporters [51], enthusiasts but culturally and environmentally concerned [41], attitudinal ambivalence [59], prudent developers [48], rational supporters [52], and concerned supporters [53] have similar profiles to realists.

On the contrary, in regions with incipient tourism development or without a significant presence of tourists, there is a profile of residents with opinions that are confusing and difficult to define. These confusing and sometimes contradictory opinions are an indication of ignorance or low knowledge of the sector, often due to a lack of direct contact with tourists [11,33,34,36,37,40,41,44,46-48,53-55,60-64].

Finally, it should be mentioned that another group appears with some frequency, but less than in the previous cases, which is characterized by responses in a personal sense. Their responses imply that they value tourism and the economic development of the region in relation to the benefits they obtain at the individual level, not taking into account the effects that may occur on the whole of society but without a direct personal impact $[11,33,34,37,46,53,63-65]$. 
Table 1. Previous cluster analysis papers (own elaboration).

\begin{tabular}{|c|c|c|c|}
\hline Ref. & Destination & Country & Clusters \\
\hline [46] & Balearic Islands & Spain & $\begin{array}{l}\text { Development supporters; prudent developers; ambivalent and cautious; } \\
\text { protectionists; alternative developers. }\end{array}$ \\
\hline [65] & Crete & Greece & Advocates; socially and environmentally concerned; economic sceptics. \\
\hline [47] & Folgaria (Trentino) & Italy & $\begin{array}{l}\begin{array}{l}\text { Environmental supporters; development supporters; protectionists; } \\
\text { ambivalents. }\end{array}\end{array}$ \\
\hline [49] & Folgaria (Trentino) & Italy & Protectionists; ambivalent and cautious; tourism supporters. \\
\hline [56] & Cruise Tourism, Cartagena de Indias & Colombia & Opponents; neutrals; developers; tourism workers. \\
\hline [66] & Oporto; Coast of Alentejo & Portugal & $\begin{array}{l}\text { Residents with low expenditures; visitors with medium expenditures; } \\
\text { more attractive visitors. }\end{array}$ \\
\hline [57] & Eight annual events in Macao & China & Embracers; realists; experiencers. \\
\hline [33] & Florida & United States & Lovers; haters; cautious romantics; in-betweeners; love 'em for a reason. \\
\hline [38] & Arzachena (Sardinia) & Italy & Enthusiastics; moderate supporters; critics; indifferents. \\
\hline [60] & Naples & Italy & Indifferents; moderate lovers; moderate critics; cautious. \\
\hline [51] & Cruise Tourism, Valencia & Spain & Pessimists; cautious supporters; optimists. \\
\hline [41] & $\begin{array}{l}\text { FIA World Rally Championship, Olbia } \\
\text { (Sardinia) }\end{array}$ & Italy & $\begin{array}{l}\text { Supporters; neutrals; enthusiasts but culturally and environmentally } \\
\text { concerned; critics. }\end{array}$ \\
\hline [67] & Pafos & Cyprus & Engagers; pragmatists; adherents; ambivalents. \\
\hline [34] & Gold Coast Indy Car Race & Australia & $\begin{array}{l}\text { Ambivalent supporters (cautious romantics); haters; realists; lovers; } \\
\text { concerned for a reason. }\end{array}$ \\
\hline [68] & Australian Formula 1 Grand Prix & Australia & Very negative; negative; unconcerned; positive; very positive. \\
\hline [61] & Tenerife; Majorca & Spain & Positive; cautious; critics. \\
\hline [42] & Adriatic Coast & Italy & Supporters; cautious; sceptics. \\
\hline [55] & Erdaobaihe & China & $\begin{array}{l}\text { Somewhat irritated; enthusiastic supporters; cautious romantics; } \\
\text { in-betweeners. }\end{array}$ \\
\hline [69] & Shanghai & China & Pecuniary benefit seeker; nature advocator; family life reliever. \\
\hline [70] & $\begin{array}{l}\text { Goldfields; The Grampians; The } \\
\text { Murray; Gippsland Natural Discovery; } \\
\text { Goulburn Murray Water (Victoria) }\end{array}$ & Australia & $\begin{array}{l}\text { Tourism industry connection; low tourism connection; neutral tourism } \\
\text { development; high tourism connection. }\end{array}$ \\
\hline [58] & Shenzhen & China & Neutrals; boosters; realists; objectors. \\
\hline [48] & Björholmen; Käringön; Marstrand & Sweden & $\begin{array}{c}\text { Development supporters; prudent developers; ambivalent/cautious; } \\
\text { skeptics. }\end{array}$ \\
\hline [35] & Sedona; York & $\begin{array}{l}\text { United States; } \\
\text { United } \\
\text { Kingdom }\end{array}$ & Haters; lovers; realists. \\
\hline [36] & Gran Canarias & Spain & $\begin{array}{c}\text { (1) Extreme tourist lovers; extreme tourist haters; ambivalents. (2) } \\
\text { Lovers; haters; ambivalents. }\end{array}$ \\
\hline [43] & Spring Break, Acapulco & Mexico & Supporters; ambivalents; re \\
\hline [62] & Old City of Dubrovnik & Croatia & Cultural and safety carers; cultural illuminators; phlegmatics. \\
\hline [50] & Termoli & Italy & Activists; disenchanted; opposers; favorers. \\
\hline [52] & Cape Verde & Cape Verde & Optimistic; rational; indifferent. \\
\hline [39] & Bakewell & $\begin{array}{l}\text { United } \\
\text { Kingdom }\end{array}$ & Enthusiast; somewhat irritated; middle-of-the-roaders. \\
\hline$[63]$ & $\begin{array}{l}\text { Rangitikei } \\
\text { Ibiza }\end{array}$ & $\begin{array}{l}\text { New Zealand } \\
\text { Spain }\end{array}$ & $\begin{array}{l}\text { Moderate enthusiasts; extreme enthusiast; cautious supporters. } \\
\text { Supporters; opposers; mild opposers. }\end{array}$ \\
\hline [64] & Goynuk; Camyuva & Turkey & $\begin{array}{l}\text { Public service and environment focused; community focused; } \\
\text { community public service; inconsequential. }\end{array}$ \\
\hline [71] & Eilat & Israel & Nature aesthete; appreciator; critical. \\
\hline [37] & Southern Lakes Region & New Zealand & Lovers; we miss out; self-interest supporters; critics. \\
\hline [72] & Guimarães & Portugal & Sceptics; moderately optimistic; enthusiasts. \\
\hline [53] & Ecotourism & Cambodia & $\begin{array}{l}\text { Absolute supporter; beneficiary supporter; concerned supporter; } \\
\text { ambivalent. }\end{array}$ \\
\hline [54] & Central Vietnam & Vietnam & High-support; low-support; neutral. \\
\hline [40] & Hong Kong & China & Middle-of-the-roaders; enthusiasts; somewhat irritated. \\
\hline [44] & Tamborine Mountain (Queensland) & Australia & Supporters; opponents; neutrals. \\
\hline [45] & $\begin{array}{l}\text { Gold Coast } \\
\text { Auckland; Blenheim; Christchurch; }\end{array}$ & Australia & Supporters; conditional supporters; conditional opponents; opponents. \\
\hline [11] & $\begin{array}{c}\text { Hokitika; Kaikoura; Napier; } \\
\text { Queenstown; Rotorua; Taupo; } \\
\text { Whangarei }\end{array}$ & New Zealand & Lovers; cynics; taxpayers; innocents. \\
\hline
\end{tabular}


These similarities in the results of the existing literature led Ramón and Serra [19] to propose a theoretical model with five groups of residents whose relative weight would depend on the specific tourist destination (phase of the life cycle, endogenous or exogenous development, cultural differences with tourists and immigrants, etc.): Enthusiastic supporters; supporters with a nuanced opinion; interested supporters; critics; without a formed opinion. Finally, it should be noted that these authors indicated that the five groups do not always have to occur, although usually enthusiastic supporters and critics do appear [19].

Cluster analyses are characterized by asking residents about their perceptions and attitudes toward tourism in the region, an event held in the region or a specific type of tourism, but their attitudes toward other aspects of tourism, such as the degree of acceptance of different types of offers, have not yet been raised via cluster analysis. On this last case, it allows determining clusters based on combinations of acceptable offers; in reality, it would be a multi-offer cluster analysis that defines positions for all types of offers simultaneously. This last type of cluster analysis is the objective of this article and aims to answer the questions raised in the introduction, and specified in a general hypothesis (Hypothesis 1.) and several sub-hypotheses (Hypothesis 1a and 1b):

Hypothesis 1 (H1). The residents are divided into groups with clear differences in their attitudes.

Hypothesis 1a (H1a). The differences between groups are due to the level of general acceptance of the tourism sector.

Hypothesis $\mathbf{1 b} \mathbf{( H 1 b ) . ~ T h e ~ d i f f e r e n c e s ~ b e t w e e n ~ g r o u p s ~ a r e ~ d u e ~ t o ~ d i f f e r e n t ~ p r e f e r e n c e s ~ i n ~ r e l a t i o n ~}$ to the types of tourism offer proposed.

\section{Methodology}

Human heterogeneity is the starting point of segmentation as an analysis technique. With the segmentation of a sample or population, it is intended to divide the initial group into internally homogeneous and externally heterogeneous subgroups. With this, more detailed information is obtained when analyzing the average responses of the sample and subsamples [11]. Cluster analysis is a multivariate statistical technique used for segmentation processes, with various specific techniques based on different algorithms to carry out the group formation process. In this article, a cluster analysis was performed using one of the most popular techniques, the K-means algorithm [73-75]. The K-means algorithm is based on the distances between cases and assigns the cases to a number of clusters (in this case, it was tested with several possible numbers of clusters, seeking the highest possible explanatory power but keeping a limited number of clusters) with characteristics still unknown but based on a set of specified variables (in this case, the 13 types of tourism offer). The operation of the K-means algorithm starts from some initial cluster centers and assigns cases to the clusters to later recalculate the cluster centers. This process is repeated until there is an improvement in the internal homogeneity and external heterogeneity. The decision to use the k-means algorithm is due to its longest tradition in the segmentation studies of residents' attitudes and because it facilitates comparability of results with other similar studies, although it should be noted that other descending clustering techniques offer quite similar results.

The questionnaire used consisted of items with a Likert scales and a battery of sociodemographic questions aimed to define the profile of the sample (Table 2) and the groups generated in the analysis. The items used in this questionnaire were extracted from previous academic literature and from interviews with the professionals, academics, and residents of the island. For the analysis of this article, 13 items were measured using a five-point Likert scale, 1 being "Totally unacceptable" and 5 "Totally acceptable." These 13 items used to generate the groups were determined based on interviews with academics and residents, since the use of item scales with these characteristics had not been proposed in the previous literature. The questionnaire does not cover all of the elements of the offer, 
but it does cover all those that are controversial or of strategic interest to DMOs, companies, and social groups, having an impact on the local media.

Table 2. Sociodemographic profile of the sample (own elaboration).

\begin{tabular}{|c|c|c|}
\hline Variable & Frequency & $\%$ \\
\hline \multicolumn{3}{|l|}{ Sex: } \\
\hline Man & 242 & $37.58 \%$ \\
\hline Woman & 401 & $62.27 \%$ \\
\hline Did not respond & 1 & $0.16 \%$ \\
\hline \multicolumn{3}{|l|}{ Age: } \\
\hline Under 30 years old & 160 & $24.84 \%$ \\
\hline Between 30 and 45 years old & 241 & $37.42 \%$ \\
\hline Between 46 and 60 years old & 169 & $26.24 \%$ \\
\hline Greater than 60 years old & 47 & $7.30 \%$ \\
\hline Did not respond & 27 & $4.19 \%$ \\
\hline \multicolumn{3}{|l|}{ Education: } \\
\hline None & 15 & $2.33 \%$ \\
\hline Primary school & 171 & $26.55 \%$ \\
\hline Secondary school & 256 & $39.75 \%$ \\
\hline University & 196 & $30.43 \%$ \\
\hline Did not respond & 6 & $0.93 \%$ \\
\hline \multicolumn{3}{|l|}{ Municipality: } \\
\hline Eivissa & 238 & $36.96 \%$ \\
\hline Sant Antoni de Portmany & 119 & $18.48 \%$ \\
\hline Sant Joan de Labritja & 18 & $2.80 \%$ \\
\hline Sant Josep de sa Talaia & 94 & $14.60 \%$ \\
\hline Santa Eulària des Riu & 175 & $27.17 \%$ \\
\hline \multicolumn{3}{|l|}{ It feels integrated: } \\
\hline Yes & 500 & $77.64 \%$ \\
\hline No & 115 & $17.86 \%$ \\
\hline I do not know & 27 & $4.19 \%$ \\
\hline Did not respond & 2 & $0.31 \%$ \\
\hline \multicolumn{3}{|l|}{ Work in the tourism sector: } \\
\hline Yes & 375 & $58.23 \%$ \\
\hline No & 259 & $40.22 \%$ \\
\hline Did not respond & 10 & $1.55 \%$ \\
\hline
\end{tabular}

The field work was carried out over several months and a sampling by zones was used, contacting residents in the streets, shops, and bars of various urban centers on the island. The questionnaires were delivered by interviewers in the selected areas, being self-completed by the people surveyed at the time or later at home and collected days later at the same initial point of contact. This was done in order to avoid a low response rate from the interviewees. During the sampling process, a control of demographic variables (sex, age, job, education, area of residence, etc.) was carried out to try to control important biases. Even so, the percentage of women who responded was clearly higher than the percentage of men, something that occurs quite frequently given the traditional greater involvement of women in these types of activities, and there was a low percentage of responses among older people and those with very little education (fewer primary school responders). Both biases are difficult to compensate and are, in a certain way, acceptable as they are related to the involvement of these people in the tourism debate. Regarding the geographical distribution of the sample, there was a high adjustment to the population distribution of the island, both at the level of the municipality and the town or parish. The partially answered questionnaires were eliminated and the data used were made up of a 
sample of 644 residents from Ibiza (Spain). The maximum error allowed for a confidence level of $95 \%$ was $3.94 \%$, given the sample size, for a population comparable to infinite.

\section{Results}

With the cluster analysis, using the K-means algorithm, five clusters were obtained with significant differences in their attitudes: disappointed (11.02\%), favorable with nuances $(20.19 \%)$, moderate $(21.74 \%)$, enthusiasts but anti-nightclub $(21.58 \%)$, and enthusiasts $(25.47 \%)$. This allows accepting the hypothesis 1 . proposed. Due to the process followed by the algorithm, the groups were generated based on the most controversial offers and with social discrepancies. This indicates that hypothesis $1 \mathrm{~b}$ is correct. To describe the characteristics of the groups generated in the analysis, an ANOVA (Table 3) and a cross-tabulation with the sociodemographic variables (Table 4) were performed. The sociodemographic differences were minimal, but these differences can be of great help for defining groups. The existence of few differences in the sociodemographic variables may indicate that the differences in the various profiles were due to other variables, as some authors have already indicated [33,39].

Table 3. Average values of the conserved clusters (own elaboration).

\begin{tabular}{|c|c|c|c|c|c|c|c|c|c|}
\hline Type of Offer & Statistics & Total Sample & Disappointed & $\begin{array}{c}\text { Favorable with } \\
\text { Nuances }\end{array}$ & Moderate & $\begin{array}{l}\text { Enthusiasts but } \\
\text { Anti-Nightclub }\end{array}$ & Enthusiasts & Snedecor's F & $p$ Value \\
\hline \multirow{2}{*}{ All Inclusive } & Average: & 2.189 & 2.451 & 1.623 & 2.629 & 1.669 & 2.591 & 24.792 & 0.000 \\
\hline & Deviation: & 1.262 & 1.059 & 0.844 & 1.359 & 0.940 & 1.426 & & \\
\hline \multirow{2}{*}{ Golf Tourism } & Average: & 3.413 & 2.718 & 1.731 & 3.629 & 4.079 & 4.299 & 199.726 & 0.000 \\
\hline & Deviation: & 1.294 & 0.937 & 0.762 & 0.805 & 0.796 & 0.995 & & \\
\hline \multirow{2}{*}{ Cycle Tourism } & Average: & 4.228 & 2.930 & 4.177 & 3.829 & 4.626 & 4.835 & 126.243 & 0.000 \\
\hline & Deviation: & 0.889 & 0.811 & 0.818 & 0.726 & 0.579 & 0.432 & & \\
\hline \multirow{2}{*}{ Another Sport } & Average: & 4.351 & 3.070 & 4.354 & 3.964 & 4.755 & 4.890 & 172.080 & 0.000 \\
\hline & Deviation: & 0.789 & 0.757 & 0.666 & 0.566 & 0.446 & 0.366 & & \\
\hline \multirow{2}{*}{ Nautical Tourism } & Average: & 4.331 & 3.099 & 4.015 & 4.121 & 4.813 & 4.884 & 121.576 & 0.000 \\
\hline & Deviation: & 0.867 & 0.695 & 1.052 & 0.567 & 0.473 & 0.356 & & \\
\hline \multirow{2}{*}{ MICE Tourism } & Average: & 4.287 & 3.042 & 4.292 & 3.836 & 4.676 & 4.878 & 147.442 & 0.000 \\
\hline & Deviation: & 0.838 & 0.759 & 0.684 & 0.628 & 0.614 & 0.395 & & \\
\hline \multirow{2}{*}{ Nature Tourism } & Average: & 4.460 & 3.014 & 4.731 & 4.021 & 4.842 & 4.921 & 203.921 & 0.000 \\
\hline & Deviation: & 0.815 & 0.847 & 0.444 & 0.732 & 0.402 & 0.292 & & \\
\hline \multirow{2}{*}{ Rural Tourism } & Average: & 4.523 & 3.225 & 4.669 & 4.236 & 4.842 & 4.945 & 163.266 & 0.000 \\
\hline & Deviation: & 0.738 & 0.826 & 0.532 & 0.628 & 0.420 & 0.228 & & \\
\hline \multirow{2}{*}{$\begin{array}{c}\text { Vacation Homes for } \\
\text { Rent }\end{array}$} & Average: & 4.107 & 3.239 & 3.900 & 3.750 & 4.410 & 4.695 & 59.147 & 0.000 \\
\hline & Deviation: & 0.917 & 0.721 & 0.919 & 0.887 & 0.785 & 0.567 & & \\
\hline \multirow{2}{*}{ Cultural Tourism } & Average: & 4.402 & 3.099 & 4.608 & 4.007 & 4.719 & 4.872 & 131.545 & 0.000 \\
\hline & Deviation: & 0.825 & 0.875 & 0.488 & 0.742 & 0.612 & 0.401 & & \\
\hline \multirow{2}{*}{ Nightlife Tourism } & Average: & 3.002 & 2.873 & 2.277 & 3.236 & 1.950 & 4.323 & 137.834 & 0.000 \\
\hline & Deviation: & 1.317 & 1.233 & 1.164 & 1.099 & 0.762 & 0.634 & & \\
\hline \multirow{4}{*}{$\begin{array}{l}\text { Tourism of Second } \\
\text { Residence } \\
\text { Family Sun and } \\
\text { Beach Tourism }\end{array}$} & Average: & 3.882 & 3.042 & 3.515 & 3.579 & 4.108 & 4.604 & 49.324 & 0.000 \\
\hline & Deviation: & 1.067 & 0.971 & 1.132 & 0.964 & 0.942 & 0.668 & & \\
\hline & Average: & 4.337 & 3.535 & 4.223 & 4.050 & 4.554 & 4.835 & 47.932 & 0.000 \\
\hline & Deviation: & 0.845 & 0.976 & 0.757 & 0.856 & 0.770 & 0.402 & & \\
\hline
\end{tabular}


Table 4. Sociodemographic profile of the conserved clusters (own elaboration).

\begin{tabular}{|c|c|c|c|c|c|c|c|c|}
\hline Variable & $\begin{array}{c}\text { Total } \\
\text { Sample }\end{array}$ & Disappointed & $\begin{array}{c}\text { Favorable with } \\
\text { Nuances }\end{array}$ & Moderate & $\begin{array}{l}\text { Enthusiasts but } \\
\text { Anti-Nightclub }\end{array}$ & Enthusiasts & Chi-Square & $p$ Value \\
\hline Sex: & & & & & & & 5.545 & 0.236 \\
\hline Man & $37.58 \%$ & $39.44 \%$ & $29.23 \%$ & $37.86 \%$ & $38.85 \%$ & $42.07 \%$ & & \\
\hline Woman & $62.27 \%$ & $59.15 \%$ & $70.77 \%$ & $62.14 \%$ & $61.15 \%$ & $57.93 \%$ & & \\
\hline Did not respond & $0.16 \%$ & $1.41 \%$ & $0.00 \%$ & $0.00 \%$ & $0.00 \%$ & $0.00 \%$ & & \\
\hline Age: & & & & & & & 38.335 & 0.000 \\
\hline Under 30 years old & $24.84 \%$ & $35.21 \%$ & $31.54 \%$ & $25.71 \%$ & $12.23 \%$ & $25.00 \%$ & & \\
\hline Between 30 and 45 years old & $37.42 \%$ & $29.58 \%$ & $43.08 \%$ & $33.57 \%$ & $33.81 \%$ & $42.68 \%$ & & \\
\hline Between 46 and 60 years old & $26.24 \%$ & $22.54 \%$ & $18.46 \%$ & $28.57 \%$ & $35.25 \%$ & $24.39 \%$ & & \\
\hline Greater than 60 years old & $7.30 \%$ & $4.23 \%$ & $6.15 \%$ & $10.00 \%$ & $12.23 \%$ & $3.05 \%$ & & \\
\hline Did not respond & $4.19 \%$ & $8.45 \%$ & $0.77 \%$ & $2.14 \%$ & $6.47 \%$ & $4.88 \%$ & & \\
\hline Education: & & & & & & & 29.359 & 0.004 \\
\hline None & $2.33 \%$ & $5.63 \%$ & $1.54 \%$ & $1.43 \%$ & $4.32 \%$ & $0.61 \%$ & & \\
\hline Primary school & $26.55 \%$ & $25.35 \%$ & $19.23 \%$ & $35.71 \%$ & $26.62 \%$ & $25.00 \%$ & & \\
\hline Secondary school & $39.75 \%$ & $40.85 \%$ & $37.69 \%$ & $42.14 \%$ & $38.85 \%$ & $39.63 \%$ & & \\
\hline University & $30.43 \%$ & $25.35 \%$ & $41.54 \%$ & $18.57 \%$ & $30.22 \%$ & $34.15 \%$ & & \\
\hline Did not respond & $0.93 \%$ & $2.82 \%$ & $0.00 \%$ & $2.14 \%$ & $0.00 \%$ & $0.61 \%$ & & \\
\hline Municipality: & & & & & & & 32.100 & 0.010 \\
\hline Eivissa & $36.96 \%$ & $46.48 \%$ & $32.31 \%$ & $30.71 \%$ & $42.45 \%$ & $37.20 \%$ & & \\
\hline Sant Antoni de Portmany & $18.48 \%$ & $8.45 \%$ & $12.31 \%$ & $25.71 \%$ & $17.99 \%$ & $21.95 \%$ & & \\
\hline Sant Joan de Labritja & $2.80 \%$ & $4.23 \%$ & $1.54 \%$ & $2.86 \%$ & $2.88 \%$ & $3.05 \%$ & & \\
\hline Sant Josep de sa Talaia & $14.60 \%$ & $15.49 \%$ & $16.15 \%$ & $9.29 \%$ & $15.11 \%$ & $17.07 \%$ & & \\
\hline Santa Eulària des Riu & $27.17 \%$ & $25.35 \%$ & $37.69 \%$ & $31.43 \%$ & $21.58 \%$ & $20.73 \%$ & & \\
\hline It feels integrated: & & & & & & & 9.540 & 0.299 \\
\hline Yes & $77.64 \%$ & $64.79 \%$ & $76.15 \%$ & $82.14 \%$ & $80.58 \%$ & $78.05 \%$ & & \\
\hline No & $17.86 \%$ & $26.76 \%$ & $20.00 \%$ & $13.57 \%$ & $16.55 \%$ & $17.07 \%$ & & \\
\hline I do not know & $4.19 \%$ & $7.04 \%$ & $3.85 \%$ & $3.57 \%$ & $2.88 \%$ & $4.88 \%$ & & \\
\hline Did not respond & $0.31 \%$ & $1.41 \%$ & $0.00 \%$ & $0.71 \%$ & $0.00 \%$ & $0.00 \%$ & & \\
\hline Work in the tourism sector: & & & & & & & 4.705 & 0.319 \\
\hline Yes & $58.23 \%$ & $50.70 \%$ & $53.08 \%$ & $60.71 \%$ & $59.71 \%$ & $62.20 \%$ & & \\
\hline No & $40.22 \%$ & $45.07 \%$ & $46.92 \%$ & $37.86 \%$ & $38.85 \%$ & $35.98 \%$ & & \\
\hline Did not respond & $1.55 \%$ & $4.23 \%$ & $0.00 \%$ & $1.43 \%$ & $1.44 \%$ & $1.83 \%$ & & \\
\hline
\end{tabular}

The first aspect to indicate, in relation to the average values, is that most of the offers achieved a high level of acceptance (scores above four points), except "all inclusive," golf tourism, nightlife tourism, and tourism of second residence. Golf courses and tourism of second residence obtained positive average values, but they were lower than the rest (3.41 for golf and 3.88 for second residence). This is due to the fact that they are two activities linked to real estate development (golf course projects usually include adjoining real estate developments) and, therefore, a high consumption of land. Nightlife tourism achieved an average response of indifference due to two elements that worry residents: the negative impact of nightclubs and events on the neighborhood (given the distribution of the population, it is impossible to locate a nightclub without having homes nearby) and the fear of an imitation effect among the resident youth. Finally, the hotel with "all inclusive" offer was valued as unacceptable by the study sample, and by the five clusters created. The "all inclusive" offer allows hotels to withhold the expense of tourists, but causes significant damage to the complementary offer, especially bars, cafes, and restaurants. In addition, as they hardly ever leave the hotel, the tourists of this offer show little interest in the region, its environment, and its population, something that can be interpreted as contempt toward the local society. If the clusters are analyzed, differences in the opinions of the residents can be seen:

- Disappointed (11.02\%). The members of this cluster provided moderate responses, close to indifference, for most offers (Table 3). Only family sun and beach tourism (acceptable with 3.54) and "all inclusive" (unacceptable with 2.45) obtained clearly different ratings of 3 (indifference). The most common sociodemographic profile was 
people under 30 years of age and mostly residents of the municipalities of Eivissa and Sant Joan, with little presence in the municipality of Sant Antoni (Table 4).

- Favorable with nuances (20.19\%). The members of this cluster valued sport, nautical, MICE ("Meetings, Incentives, Conferences \& Exhibitions"), nature, rural, cultural, and family tourism very positively. They valued moderately positively the tourism of second residences and vacation homes for rent. Nightlife tourism was considered unacceptable, while golf tourism and "all inclusive" were very unacceptable (Table 3). The most common sociodemographic profile was people under 46 years old, with a higher education level, and mostly residents in the municipality of Santa Eulària, with little presence in the municipality of Sant Antoni (Table 4). This cluster showed a more complex and selective response to the proposed offers.

- Moderate (21.74\%). The members of this cluster positively valued all tourist offers, except "all inclusive" (Table 3). The most common sociodemographic profile was people over 60 years old, with primary education, and mostly residents in the municipality of Sant Antoni, with little presence in the municipality of Sant Josep (Table 4). These were elderly people living in the center of the island and partially isolated from tourism.

- Enthusiasts but anti-nightclub (21.58\%). The members of this cluster positively valued the majority of tourist offers (scores higher than four), but rejected the offers of nightlife and "all inclusive" (Table 3). The most common sociodemographic profile was people over 45 years old and mostly residents of the municipality of Eivissa, with little presence in the municipality of Santa Eulària (Table 4).

- Enthusiasts (25.47\%). The members of this cluster demonstrated very high levels of acceptance for most tourist offers (scores above four), but rejected "all inclusive" (Table 3). The sociodemographic profile corresponds to people who were mainly residents in the municipalities of Sant Antoni and Sant Josep, with little presence in the municipality of Santa Eulària (Table 4). There was only a scarce presence of people over 60 years of age.

In general, the differences between clusters were due to the degree of acceptance of the tourist offers and to the degree of specific acceptance of golf and nightlife tourism. The differences between groups in the average acceptance of the different offers allow us to accept hypothesis $1 \mathrm{a}$.

\section{Discussion}

Analysis of residents' attitudes toward different types of tourism is unusual, since attitudes toward a specific type of tourism are usually analyzed. In this case, a first approximation was made based on a battery of items that asked about the degree of acceptance of different tourist offers, current or potential, on the island of Ibiza. An initial descriptive analysis showed that the "all inclusive" option offered by some hotels is clearly opposed among residents. Other offers, such as golf and nightlife tourism, showed ratings indicative of low acceptance and, consequently, found positions within the population. The rest of the proposed offers, mainly linked to the cultural and natural heritage of the island, had high levels of acceptance.

This can be interpreted as a preference for tourism that values the traditional elements of the land (forests and farmlands, trails and roads, coasts and coves, etc.) - that is, the cultural landscape of Ibiza - and a distrust of offers that include significant consumption of land, such as golf courses and second homes, or with a strong impact on the life of the population scattered throughout the island, such as nightclubs and villas offered as second homes.

Cluster analysis allows to unravel the complexity hidden behind the average values of a sample. In this case, the existence of five clusters with different profiles in their degree of acceptance of tourist offers was determined. Three clusters only rejected "all inclusive" among the offers, but not in a very strong way, and they homogeneously valued the rest of the offers, going from indifference or slight acceptance (disappointed) to strong 
acceptance (enthusiasts), passing through moderate acceptance (moderates). The other two groups were variants of the moderates (this is the case of favorable with nuances) and the enthusiasts (this is the case of enthusiasts but anti-nightclub). What differentiates these two groups is that the offers were generally accepted, but with a clear rejection of nightlife in the case of the enthusiasts but anti-nightclub and golf tourism and nightlife in the case of favorable with nuances. In addition, the enthusiasts but anti-nightclub and favorable with nuances clusters showed a greater rejection of "all inclusive" than the other three groups. These responses, with a clear position against and in favor of each type of offer, indicate a more reflexive and, in a certain way, rational response than in the other three groups. If analyzed by municipalities (Figure 1), there are differences that may be related specifically to tourist development:

- The capital of the island is located in the municipality of Eivissa, eminently urban (little surface and a lot of population) and located between different areas of nightlife. Therefore, it has a higher proportion of enthusiasts but anti-nightclub members than the rest of the municipalities, since many residents suffer from noise and traffic generated by the large nightclubs of Playa d'en Bossa (Sant Josep), Sant Rafel (Sant Antoni), and, to a lesser extent, the promenade of the city itself.

- Sant Antoni is the municipality that first developed tourism and concentrates much of the nightlife. The rest of the nightlife areas of the island are less problematic and of later creation. In Sant Antoni, there are few disappointed and favorable with nuances members and enough moderate and enthusiast members, due to the dependency of tourism that the municipality possesses.

- Sant Joan is the municipality located further north, with a smaller population and less tourist development. The north of the island is where the culture, heritage, farmlands, and forests are preserved in the best condition, Es Amunts (an area parallel to the north and northwest coast, and located almost entirely in the municipality of Sant Joan) being the main landscape attraction of Ibiza. Sant Joan has more people with a moderate response (disappointed) and fewer people with a nuanced response (favorable with nuances) than the average, which is logical since it is the most distant area from the tourist centers and has more to lose in uncontrolled tourist and urban development.

- Sant Josep was the second municipality to develop tourism, showing fewer moderate responses than the average (moderate) and more clearly favorable answers, with (favorable with nuances) or without (enthusiasts) nuances. It is a municipality with high tourism development, especially on its coast, depending greatly on the sector but also crowded and with little margin for developments that involve large consumption of land.

- Santa Eulària extends through the center and northeast of the island; it developed tourism later than Sant Antoni and Sant Josep, and from the beginning decided to learn from the other municipalities and avoided potentially conflictive tourism. Santa Eulària stands out for the presence of moderate (moderate) or nuanced (favorable with nuances) opinions and has a lower presence of enthusiastic positions than the rest of the municipalities (enthusiasts and enthusiasts but anti-nightclub). It is a municipality that has been applying a tourism policy that fits completely with the vision of the favorable with nuances cluster, with some offers being highly valued and enhanced while others are avoided due to their negative impact on the population, quality of life, and land. 


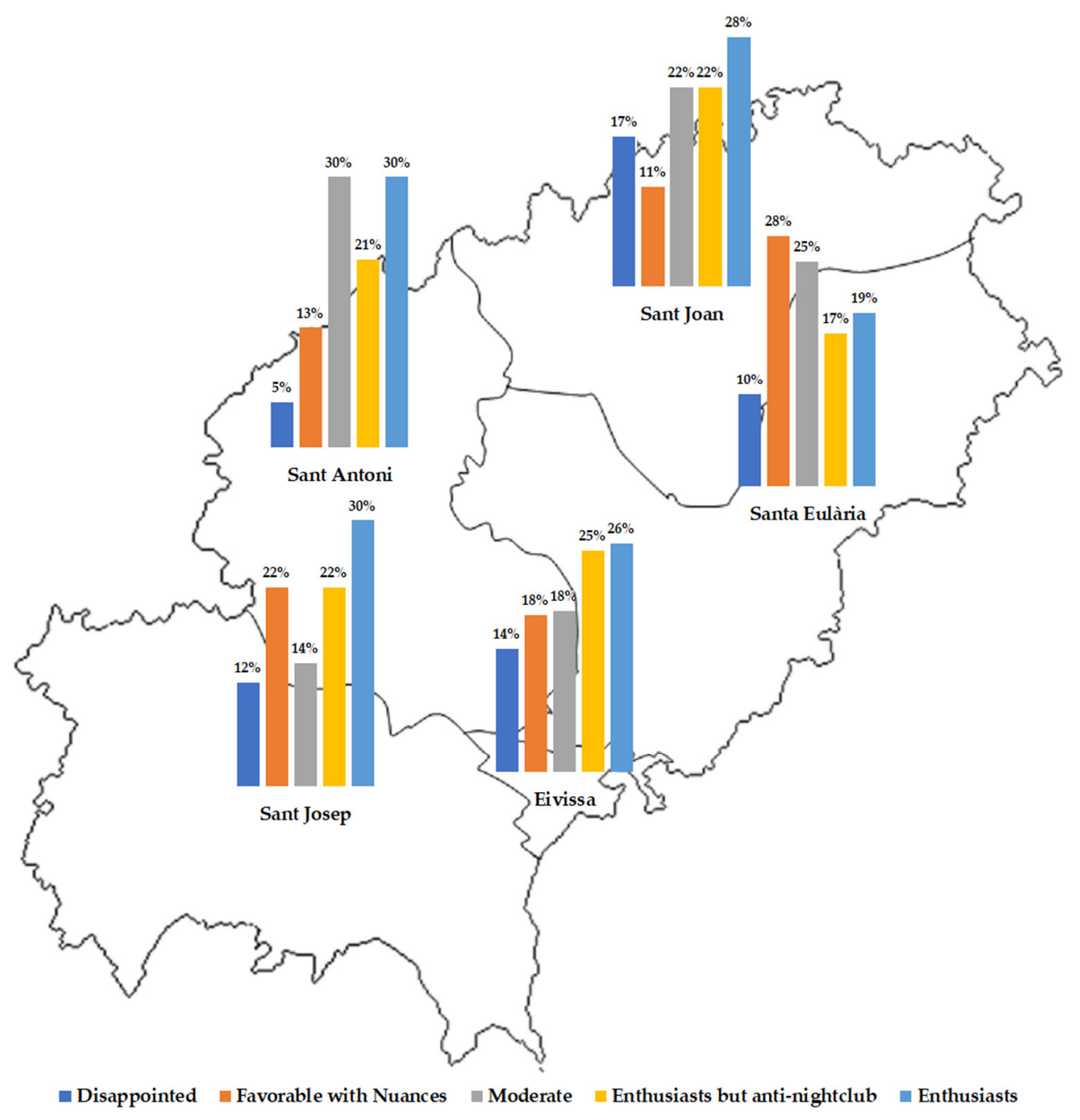

Figure 1. Profile by municipalities (source: own elaboration).

This indicates that the place of residence has an influence on the preferences of the residents and on the degree of acceptance of tourist offers. The characteristics of the immediate surroundings of the place of residence are fundamental in this regard, with the north of the island being the area most concerned with certain types of tourism and specific offers.

\section{Conclusions}

In recent decades, interest in the study of tourism in coastal areas has grown [76], and it is evident that the constant search for economic value generates conflict between tourism development and the landscape of these areas [77], as well as with the local community, caused, among other things, by the design of the tourist offer and the subsequent overwhelming visit of tourists. Thus, it has become imperative to understand the opinion on these aspects of one of the most important stakeholders in the tourism business - the residents.

For the case of Ibiza, in relation to the types of tourism offers, groups of residents with different profiles in terms of preferences and degrees of acceptance were also profiled. In this case, five clusters were detected with different intensities in the acceptance of tourist offers. Some offers were mostly considered unacceptable due to their negative consequences for the economy and society, as in the case of "all inclusive." Other offers were mostly considered acceptable because they imply an interest in the local landscape, culture, and society, such as cultural, rural, and sports tourism. Finally, there are offers with opposing positions, some in favor and others against, such as golf courses and nightlife. 
This last type of offer is one of the elements that differentiates the clusters of this study. In addition, there was a different distribution of the clusters according to the area of residence and the characteristics of tourism in that area.

For DMOs, these results imply that there are offers that should be avoided due to their high rejection and others boosted by their high acceptance. However, the difficulties for managers come from the controversial offers, which force them to work in a situation of polarization between neighbors. These are offers with an important capacity to attract tourists with high economic power, but have a strong impact on the neighbors of the facilities (golf courses, nightclubs, etc.). In this case, there is a confrontation between the economic benefits it brings and the sociocultural costs that it can generate. It is in these types of offers where the work of managers is more complex, trying to maximize the economic benefits and minimize the costs for the neighbors, and convincing the residents. In the case of Ibiza, a mature destination that is highly dependent on tourism, offers that imply enhancing the island's landscape and culture, with a low consumption of resources, should be a priority in future development. Additionally, offers with a high consumption of land (e.g., golf courses) or that pose a serious inconvenience to a resident population scattered throughout the island (e.g., nightclubs) should be avoided. The most valued offers are those that imply an enhancement of existing territorial attractions and those that least value those that have strong negative impacts on the surrounding territory (buildings, noise, supply crisis, etc.), in addition to having differences in preferences according to the area of the island and the characteristics of the territory of that area, thus solving problems related to the land.

In future studies, this type of analysis should be repeated in other tourist destinations and the types of offers analyzed should be broadened. With a view to future repetitions of this study, the list of tourist offers that the respondents are asked about should be expanded and revised, since in this case some very important offers remained untreated. The elaboration of this scale is by itself a new theoretical contribution. Once the new scale has been drawn up, it must be reviewed for each specific case which offers should be kept in the analysis. The list applied to each specific case must contain all the offers from the general list that are technically possible in the destination under analysis. Subsequent fieldwork would follow a similar structure to this article and similar articles on residents' attitudes.

It is also a weak point that it is a case study, that is, a specific destination with its peculiarities, and conclusions cannot be generalized to other destinations beyond some trends. Another limitation is the algorithm used to generate the clusters. The algorithm and the variables taken into consideration influence the final result, although the differences in the results are usually limited between the different algorithms. For this reason, in this case, the most frequent algorithm has been used, something that is recommended for future analysis.

Author Contributions: Conceptualization, D.D.P.-M. and J.R.-C.; methodology, J.R.-C.; validation, D.D.P.-M. and M.D.S.-F.; formal analysis, J.R.-C.; data curation, M.D.S.-F.; writing-original draft preparation, J.R.-C.; writing-review and editing, D.D.P.-M. and M.D.S.-F. All authors have read and agreed to the published version of the manuscript.

Funding: The APC was funded by the University of Magdalena, Colombia.

Data Availability Statement: The data presented in this study are available on request from the corresponding author.

Conflicts of Interest: The authors declare no conflict of interest.

\section{References}

1. Serra, A.; Ramón, J. Host community resignation to nightclub tourism. Curr. Issues Tour. 2017, 20, 566-579. [CrossRef]

2. Sharpley, R. Host perceptions of tourism: A review of the research. Tour. Manag. 2014, 42, 37-49. [CrossRef]

3. Stylidis, D.; Terzidou, M. Tourism and the economic crisis in Kavala, Greece. Ann. Tour. Res. 2014, 44, 210-226. [CrossRef]

4. Tovar, C.; Lockwood, M. Social impacts of tourism: An Australian regional case study. Int. J. Tour. Res. 2008, 10, 365-378. [CrossRef] 
5. Vargas, A.; Plaza, M.A.; Porras, N. Understanding residents' attitudes toward the development of industrial tourism in a former mining community. J. Travel Res. 2009, 47, 373-387. [CrossRef]

6. Ap, J.; Crompton, J.L. Developing and testing a tourism impact scale. J. Travel Res. 2018, 37, 120-130. [CrossRef]

7. Byrd, E.T.; Bosley, H.E.; Dronberger, M.G. Comparisons of stakeholder perceptions of tourism impacts in rural eastern North Carolina. Tour. Manag. 2009, 30, 693-703. [CrossRef]

8. Eusébio, C.; Vieira, A.L.; Lima, S. Place attachment, host-tourist interactions, and residents' attitudes towards tourism development: The case of Boa Vista Island in Cape Verde. J. Sustain. Tour. 2018, 26, 890-909. [CrossRef]

9. Gursoy, D.; Chi, C.G.; Dyer, P. Locals' attitudes toward mass and alternative tourism: The case of Sunshine Coast, Australia. J. Travel Res. 2010, 49, 381-394. [CrossRef]

10. Nunkoo, R.; Ramkissoon, H. Power, trust, social exchange and community support. Ann. Tour. Res. 2012, 39, 997-1023. [CrossRef]

11. Williams, J.; Lawson, R. Community issues and resident opinions of tourism. Ann. Tour. Res. 2001, 28, 269-290. [CrossRef]

12. Almeida, F.; Balbuena, A.; Cortés, R. Resident's attitudes towards the impacts of tourism. Tour. Manag. Perspect. 2015, 13, 33-40. [CrossRef]

13. Brida, J.G.; Chiappa, G.D.; Meleddu, M.; Pulina, M. A comparison of residents' perceptions in two cruise ports in the Mediterranean Sea. Int. J. Tour. Res. 2014, 16, 180-190. [CrossRef]

14. Cornell, D.A.V.; Tugade, L.O.; de Sagun, R. Tourism quality of life (TQOL) and local residents' attitudes towards tourism development in Sagada, Philippines. J. Tour. Dev. 2019, 31, 9-34. [CrossRef]

15. Gursoy, D.; Ouyang, Z.; Nunkoo, R.; Wei, W. Residents' impact perceptions of and attitudes towards tourism development: A meta-analysis. J. Hosp. Mark. Manag. 2019, 28, 306-333. [CrossRef]

16. Lundberg, E. The importance of tourism impacts for different local resident groups: A case study of a Swedish seaside destination. J. Dest. Mark. Manag. 2017, 6, 46-55. [CrossRef]

17. Shen, H.L.; Luo, J.; Zhao, A. The sustainable tourism development in Hong Kong: An analysis of Hong Kong residents' attitude towards mainland Chinese tourist. J. Qual. Assur. Hosp. Tour. 2017, 18, 45-68. [CrossRef]

18. Yu, C.; Huang, Y.; Yeh, P.; Chao, P. Residents' attitudes toward island tourism development in Taiwan. Isl. Stud. J. 2017, 12, 159-176. [CrossRef]

19. Ramón, J.; Serra, A. Segmentando residentes según sus actitudes: Revisión de la literatura. PASOS Rev. Tur. Patrim. Cult. 2015, 13, 837-848. [CrossRef]

20. Ibestat. Estadísticas. Institut d'Estadística de les Illes Balears. Available online: https:/ /ibestat.caib.es/ (accessed on 10 January 2021).

21. Ramón, J.; Serra, A. Historia del turismo en Ibiza: Aplicación del Ciclo de Vida del Destino Turístico en un destino maduro del Mediterráneo. PASOS Rev. Tur. Patrim. Cult. 2014, 12, 899-913. [CrossRef]

22. Frleta, D.S. Island destinations' tourism offer-tourists' vs. residents' attitudes. Tour. Hosp. Manag. 2014, 20, 1-14. [CrossRef]

23. Vargas, A.; Porras, N.; Plaza, M.A. Residents' attitude to tourism and seasonality. J. Travel Res. 2014, 53, 581-596. [CrossRef]

24. Vivek. An empirical study of residents' attitudes for sustainable tourism development in Himachal Pradesh. Int. J. Hosp. Tour. Syst. 2021, 14, 128-137.

25. Doxey, G.V. A causation theory of visitor-resident irritants: Methodology and research inferences. In Proceedings of the Conference Proceedings: Sixth Annual Conference of Travel and Tourism Research Association, San Diego, CA, USA, 8-11 September 1975; pp. 195-198.

26. Butler, R.W. The concept of a tourist area cycle of evolution: Implications for the management of resources. Can. Geogr. 1980, 24, 5-12. [CrossRef]

27. Fan, D.X.F.; Liu, A.; Qiu, R.T.R. Revisiting the relationship between host attitudes and tourism development: A utility maximization approach. Tour. Econom. 2019, 25, 171-188. [CrossRef]

28. Belisle, F.J.; Hoy, D.R. The perceived impact of tourism by residents: A case study in Santa Marta, Colombia. Ann. Tour. Res. 1980, 7, 83-101. [CrossRef]

29. Jurowski, C.; Uysal, M.; Williams, R.D. A theoretical analysis of host community resident reactions to tourism. J. Travel Res. 1997, 36, 3-11. [CrossRef]

30. Lankford, S.V.; Howard, D.R. Developing a tourism impacts attitude scale. Ann. Tour. Res. 1994, 21, 121-139. [CrossRef]

31. Um, S.; Crompton, J.L. Measuring resident's attachment levels in a host community. J. Travel Res. 1987, 26, 27-29. [CrossRef]

32. Brougham, J.E.; Butler, R.W. A segmentation analysis of resident attitudes to the social impact of tourism. Ann. Tour. Res. 1981, 8, 569-590. [CrossRef]

33. Davis, D.; Allen, J.; Cosenza, R.M. Segmenting local residents by their attitudes, interests and opinions toward tourism. J. Travel Res. 1988, 27, 2-8. [CrossRef]

34. Fredline, E.; Faulkner, B. Host community reactions: A cluster analysis. Ann. Tour. Res. 2000, 27, 763-784. [CrossRef]

35. Madrigal, R. Residents' perceptions and the role of government. Ann. Tour. Res. 1995, 22, 86-102. [CrossRef]

36. Martín, J.C.; Moreira, P.; Román, C. A hybrid-fuzzy segmentation analysis of residents' perception towards tourism in Gran Canaria. Tour. Econ. 2020, 26, 1282-1304. [CrossRef]

37. Thyne, M.; Lawson, R. Addressing tourism public policy issues through attitude segmentation of host communities. Curr. Issues Tour. 2001, 4, 392-400. [CrossRef]

38. Del Chiappa, G.; Atzeni, M.; Ghasemi, V. Community-based collaborative tourism planning in islands: A cluster analysis in the context of Costa Smeralda. J. Destin. Mark. Manag. 2018, 8, 41-48. [CrossRef] 
39. Ryan, C.; Montgomery, D. The attitudes of Bakewell residents to tourism and issues in community responsive tourism. Tour. Manag. 1994, 15, 358-369. [CrossRef]

40. Wassler, P.; Schuckert, M.; Hung, K.; Petrick, J.F. You're welcome? Hong Kong's attitude towards the individual visit scheme. Intern. J. Tour. Res. 2018, 20, 637-649. [CrossRef]

41. Del Chiappa, G.; Presenza, A.; Yücelen, M. Profiling residents based on their perceptions and attitude toward sport event: Insights from the FIA world rally championship. Tourismos 2016, 11, 26-51.

42. Gon, M.; Osti, L.; Pechlaner, H. Leisure boat tourism: Residents' attitudes towards nautical tourism development. Tour. Rev. 2016, 71, 180-191. [CrossRef]

43. Monterrubio, J.C.; Andriotis, K. Social representations and community attitudes towards spring breakers. Tour. Geogr. 2014, 16, 288-302. [CrossRef]

44. Weaver, D.B.; Lawton, L.J. Resident perceptions in the urban-rural fringe. Ann. Tour. Res. 2001, 28, 439-458. [CrossRef]

45. Weaver, D.B.; Lawton, L.J. Resident perceptions of a contentious tourism event. Tour. Manag. 2013, 37, 165-175. [CrossRef]

46. Aguiló, E.; Rosselló, J. Host community perceptions: A cluster analysis. Ann. Tour. Res. 2005, 32, 925-941. [CrossRef]

47. Brida, J.G.; Osti, L.; Barquet, A. Segmenting Resident Perceptions towards Tourism-a Cluster Analysis with a Multinomial Logit Model of a Mountain Community. Int. J. Tour. Res. 2010, 12, 591-602. [CrossRef]

48. Lundberg, E. The level of tourism development and resident attitudes: A comparative case study of coastal destinations. Scand. J. Hosp. Tour. 2015, 15, 266-294. [CrossRef]

49. Brida, J.G.; Osti, L.; Faccioli, M. Residents' perception and attitudes towards tourism impacts: A case study of the small rural community of Folgaria (Trentino-Italy). Benchmark. Int. J. 2011, 18, 359-385. [CrossRef]

50. Presenza, A.; Del Chiappa, G.; Sheehan, L. Residents' engagement and local tourism governance in maturing beach destinations. Evidence from an Italian case study. J. Dest. Mark. Manag. 2013, 2, 22-30. [CrossRef]

51. Del Chiappa, G.; Lorenzo-Romero, C.; Gallarza, M. Host community perceptions of cruise tourism in a homeport: A cluster analysis. J. Dest. Mark. Manag. 2018, 7, 170-181. [CrossRef]

52. Ribeiro, M.A.; Valle, P.O.; Silva, J.A. Residents' attitudes towards tourism development in Cape Verde islands. Tour. Geogr. 2013, 15, 654-679. [CrossRef]

53. Ven, S. Residents' participation, perceived impacts, and support for community-based ecotourism in Cambodia: A latent profile analysis. Asia Pac. J. Tour. Res. 2016, 21, 836-861. [CrossRef]

54. Wassler, P.; Nguyen, T.H.H.; Mai, L.Q.; Schuckert, M. Social representations and resident attitudes: A multiple-mixed-method approach. Ann. Tour. Res. 2019, 78, e102740. [CrossRef]

55. Gu, X.; Hunt, C.A.; Lengieza, M.L.; Niu, L.; Wu, H.; Wang, Y.; Jia, X. Evaluating residents' perceptions of nature-based tourism with a factor-cluster approach. Sustainbility 2021, 13, e119. [CrossRef]

56. Brida, J.G.; Riaño, E.; Aguirre, S.Z. Residents' attitudes and perceptions towards cruise tourism development: A case study of Cartagena de Indias (Colombia). Tour. Hosp. Res. 2011, 11, 181-196. [CrossRef]

57. Chen, S.C. Residents' perceptions of the impact of major annual tourism events in Macao: Cluster analysis. J. Conv. Environ. Tour. 2011, 12, 106-128. [CrossRef]

58. Liang, Z.; Hui, T. Residents' quality of life and attitudes toward tourism development in China. Tour. Manag. 2016, 57, 56-67. [CrossRef]

59. Chen, Z.; Wang, Y.; Li, X.; Lawton, L. It's not just black or white: Effects of ambivalence on residents' support for a mega-event. J. Hosp. Tour. Res. 2019, 43, 283-313. [CrossRef]

60. Del Chiappa, G.; Atzeni, M.; Pung, J.M.; Risitano, M. Residents' views on cruise tourism in Naples profiles and insights from a Mediterranean home-port destination. Eur. J. Tour. Res. 2019, 23, 71-85.

61. Garau, J.B.; Díaz, R.J.; Gutiérrez, D. Residents' perceptions of tourism impacts on island destinations: A comparative analysis. Int. J. Tour. Res. 2014, 16, 578-585. [CrossRef]

62. Pavlić, I.; Portolan, A.; Puh, B. Segmenting local residents by perceptions of tourism impacts in an urban world heritage site: The case of Dubrovnik. J. Herit. Tour. 2020, 15, 398-409. [CrossRef]

63. Ryan, C.; Scotland, A.; Montgomery, D. Resident attitudes to tourism development-A comparative study between the Rangitikei, New Zealand and Bakewell, United Kingdom. Prog. Tour. Hosp. Res. 1998, 4, 115-130. [CrossRef]

64. Sinclair-Maragh, G.; Gursoy, D.; Vieregge, M. Residents' perceptions toward tourism development: A factor-cluster approach. J. Dest. Mark. Manag. 2015, 4, 36-45. [CrossRef]

65. Andriotis, K.; Vaughan, R.D. Urban residents' attitudes toward tourism development: The case of Crete. J. Travel Res. 2003, 42, 172-185. [CrossRef]

66. Carneiro, M.J.; Eusébio, C.; Pelicano, M. An expenditure patterns segmentation of the music festivals' market. Int. J. Sustain. Dev. 2011, 14, 290-308. [CrossRef]

67. Farmaki, A.; Christou, P.; Saveriades, A.; Spanou-Tripinioti, E. Perceptions of Pafos as European capital of culture: Tourism stakeholder and resident perspectives. Int. J. Tour. Res. 2019, 21, 234-244. [CrossRef]

68. Fredline, L.; Deery, M.; Jago, L. A longitudinal study of the impacts of an annual event on local residents. Tour. Plan. Dev. 2013, 10, 416-432. [CrossRef]

69. Guo, Y.; Kim, S.; Chen, Y. Shanghai residents' perceptions of tourism impacts and quality of life. J. China Tour. Res. 2014, 10, 142-164. [CrossRef] 
70. Inbakaran, R.; Jackson, M. Resident attitudes inside Victoria's tourism product regions: A cluster analysis. J. Hosp. Tour. Manag. 2006, 13, 59-74. [CrossRef]

71. Stylidis, D. Residents' place image: A cluster analysis and its links to place attachment and support for tourism. J. Sustain. Tour. 2018, 26, 1007-1026. [CrossRef]

72. Vareiro, L.M.C.; Remoaldo, P.C.; Ribeiro, J.A.C. Residents' perceptions of tourism impacts in Guimarães (Portugal): A cluster analysis. Curr. Issues Tour. 2013, 16, 535-551. [CrossRef]

73. Ahmed, M.; Seraj, R.; Islam, S.M.S. The k-means algorithm: A comprehensive survey and performance evaluation. Electronics 2020, 9, e1295. [CrossRef]

74. Chen, J.; Ching, R.K.H.; Lin, Y. An extended study of the K-means algorithm for data clustering and its applications. J. Opt. Res. Soc. 2004, 55, 976-987. [CrossRef]

75. Zeebaree, D.Q.; Haron, H.; Abdulazeez, A.M.; Zeebaree, S.R.M. Combination of k-means clustering with genetic algorithm: A review. Int. J. Appl. Eng. Res. 2017, 12, 14238-14245.

76. Mooser, A.; Anfuso, G.; Gómez-Pujol, L.; Rizzo, A.; Williams, A.T.; Aucelli, P.P.C. Coastal Scenic Beauty and Sensitivity at the Balearic Islands, Spain: Implication of Natural and Human Factors. Land 2021, 10, 456. [CrossRef]

77. Wang, Z.; Marafa, L. Tourism Imaginary and Landscape at Heritage Site: A Case in Honghe Hani Rice Terraces, China. Land 2021, 10, 439. [CrossRef] 